\title{
Osmotic Laser Drilled Tablet Dosage Form
}

National Cancer Institute

\section{Source}

National Cancer Institute. Osmotic Laser Drilled Tablet Dosage Form. NCI Thesaurus.

Code C69008.

A tablet with a semi-permeable membrane composed of active and/or inert ing redient(s) and an osmotic agent with a laser drilled central core. Upon ing estion, water permeates the core and the ing redient is dissolved and released. 